\title{
Perception of drug users on family: a phenomenological study
}

\author{
Percepção de consumidores de drogas sobre família: um estudo fenomenológico \\ Percepción de consumidores de drogas sobre la familia: un estudio fenomenológico
}

\section{Janine Lemos de Lima', Patrícia Anjos Lima de Carvalho', Vanessa Thamyris Carvalho dos Santos', Márcia Aparecida Ferreira de Oliveira", Sâmia de Carliris Barbosa Malhado', Eurisa Maria de Santana"', Edite Lago da Silva Sena'}

'Universidade Estadual do Sudoeste da Bahia. Jequié, Bahia, Brazil.

"Universidade de São Paulo, Mother-Child and psychiatric nursing Department. São Paulo, Brazil.

I" Universidade Estadual de Santa Cruz, Department of Psychology and Humanities. Ilhéus, Bahia, Brazil.

\section{How to cite this article:}

Lima JL, Carvalho PAL, Santos VTC, Oliveira MAF, Malhado SCB, Santana EM, Sena ELS. Perception of drug users on family: a phenomenological study. Rev Bras Enferm [Internet]. 2018;71(Suppl 5):2094-100.

[Thematic Issue: Mental health] DOI: http://dx.doi.org/10.1590/0034-7167-2016-0368

\section{Submission: 02-13-2017 Approval: 10-01-2017}

\begin{abstract}
Objective: to understand the perception of drug users about "being a family" in the context of their psychosocial rehabilitation. Method: based on the theoretical-philosophical reference of Maurice Merleau-Ponty. It was carried out with eleven users of the Center for Psychosocial Care Alcohol and other Drugs (CAPS AD) in a municipality in the South of Bahia, Brazil, through the Focal Group, in August 2015. The resulting material was submitted to the Ambiguity Analytical Technique. Results: the readings of the descriptions allowed the definition of the thematic category: Nuances of being family: materialist and existential view. Final considerations: the results of the study converged to the understanding that the user of alcohol and other drugs recognizes the "being a family" from two dimensions: a more materialistic, and an existentialist, which need to be considered in the process of psychosocial rehabilitation of this user.
\end{abstract}

Descriptors: Nursing; Illegal Drugs; Family; Rehabilitation; Mental Health.

\section{RESUMO}

Objetivo: compreender a percepção de consumidores de drogas acerca do "ser família" no contexto de sua reabilitação psicossocial. Método: fundamentado no referencial teórico-filosófico de Maurice Merleau-Ponty. Realizado com onze usuários do Centro de Atenção Psicossocial Álcool e outras Drogas (CAPS AD) em um município da região Sul da Bahia, Brasil, por meio do Grupo Focal, em agosto de 2015. O material resultante foi submetido à técnica Analítica da Ambiguidade. Resultados: as leituras das descrições vivenciais permitiram a definição da categoria temática: Nuances do ser família: visão materialista e existencial. Considerações finais: os resultados do estudo convergiram para a compreensão de que o consumidor de álcool e outras drogas reconhece o "ser família" a partir de duas dimensões: uma mais materialista e outra existencialista, as quais precisam ser consideradas no processo de reabilitação psicossocial desse usuário.

Descritores: Enfermagem; Drogas Ilícitas; Família; Reabilitação; Saúde Mental.

\section{RESUMEN}

Objetivo: comprender la percepción de los consumidores de drogas acerca del ser familiar en el contexto de su rehabilitación psicosocial. Método: fundamentado en el referencial teórico-filosófico de Maurice Merleau-Ponty. Realizado el estudio con once usuarios del Centro de Atención Psicosocial Alcohol y otras Drogas (Caps ad) en un municipio de la región Sur de Bahía, Brasil, a través del Grupo Focal, en agosto 2015. El material resultante fue sometido a la técnica Analítica de la Ambigüedad. Resultados: las lecturas de las descripciones vivenciales permitieron la definición de la categoría temática: Nuances del ser familia: una visión materialista y existencial. Consideraciones finales: los resultados del estudio convergieron para la comprensión de que 
el consumidor de alcohol y otras drogas reconoce el "ser familia" a partir de dos dimensiones: una más materialista y otra existencialista, las cuales necesitan ser consideradas en el proceso de rehabilitación psicosocial de ese usuario.

Descriptores: Enfermería; Las Drogas Ilícitas; Familia; Rehabilitación; Salud Mental.

\section{CORRESPONDING AUTHORＥdite Lago da Silva Sena E-mail: editelago@gmail.com}

\section{INTRODUCTION}

Family, seen as an open system that has its own identity and multidirectional communication ${ }^{(1)}$, is a care unit with dynamic and complex organization whose members are largely influenced by the economic, political and social structure in which it is inserted. In this space, are defined spiritual, social, ethical, moral and conceptual values of the human being ${ }^{(2-3)}$.

The countless changes and transformations of the $20^{\text {th }}$ and $21^{\text {st }}$ centuries have produced reflections on family relationships, intensifying new and varied arrangements, as well as altering conceptions of conjugality and parenting ${ }^{(4)}$. For these authors, the formation of family arrangements, seen as a type of organization, does not have to do with the fact of having or not blood ties, including nuclear families (father, mother and children), extended (including three or four generations), LGBT parenting (same-sex couples, with or without children), monoparental (headed only by one of the parents) and blended (after marital separation) $)^{(4)}$.

In the midst of so many changes that the family has been suffering, scholars have come to see it as an object of study in the various areas of knowledge; such as psychology, sociology, anthropology and health; since it is one of the social devices in which human interrelations can be understood, in their nuances and micropolitical unfoldings, established by affective relationships and power among their members. This perspective leads us to the understanding of the family as a dynamic, complex, global, diverse and unique social structure, among other aspects that characterize its multidimensionality and surpass the definitions associated to consanguinity and affinity ${ }^{(5)}$.

Family can constitute as much a factor of adversity as of protection to the processes of health and illness of its members ${ }^{(1)}$. This is because their relationships are modified when one of the members presents a health problem, such as alcoholism, which can either disrupt the family or can awaken in it processes of adaptation and resilience ${ }^{(1)}$.

The consumption of alcohol and other drugs can not be understood without considering the structural and organizational changes currently presented in the family nucleus, a problem that is influenced by numerous factors that cross social, cultural, economic, political, and other issues that involve modern society. Therefore, service professionals, family members and users need to recognize this context and begin to define strategies to overcome this challenge, with a view to increasing resilience and building possibilities for psychosocial rehabilitation, including actions aimed at both users and their families ${ }^{(6)}$.

Faced with the diversity of factors and the complexity involved in drug use, the Ministry of Health created the Programa Nacional de Atenção Integrada aos Usuários de Álcool e outras Drogas (freely translated as National Integrated Program for Users of Alcohol and Other Drugs) with the objective of organizing actions for the promotion, prevention, protection and health of these users, from a strategic network of out-of-hospital services and which includes family participation, articulated to the psychosocial care network and based on the harm reduction approach ${ }^{(7)}$.

Thus, the family, seen in the context of the Brazilian policy on drugs as an indispensable support in the process of rehabilitation of people who consume alcohol and other drugs in a habitual way, is now considered as a treatment partner, identified as the foundation and source of maintaining the social bond of its relative ${ }^{(8)}$. In addition, the family can be seen by health care professionals as being in need of care, which suggests maintaining a social support network that is capable of breaking with the fragmented care model focused on the drug user alone ${ }^{(9)}$.

In our experience in mental health services, in a municipality in the southern region of Bahia, more specifically in the Center for Psychosocial Care alcohol and other drugs (CAPS AD), we noticed the absence of families in the activities developed by the mental health team. This deeply disturbed us and made us reflect on the role of the family in the therapeutic itinerary and psychosocial rehabilitation of a family member who consumes drugs in the usual way.

When we realize that, despite the Política Nacional de Saúde Mental (National Mental Health Policy) advocating family coresponsibility for the psychosocial rehabilitation of mental health service users, family members remain distant from this process; and when we recognize that the family can be a protective factor by contributing to the resilience and empowerment of its members, we have the idea of conducting a research based on the following question: how do CAPS AD users see the family in the context of their psychosocial rehabilitation?

\section{OBJECTIVE}

To understand the perception of drug users about "being a family" in the context of their psychosocial rehabilitation, in light of Merleau-Ponty's phenomenological approach.

\section{METHOD}

\section{Ethical aspects}

We obtained authorization from the participants through the signing of the Informed Consent Term. The research project was approved by the Research Ethics Committee of the Universidade Estadual do Sudoeste da Bahia (UESB), respecting the legal provisions for research with human beings, in accordance with Resolution of the Conselho Nacional de Saúde (National Health Council) 466/12(10).

\section{Theoretical-methodological framework and type of study}

This is a phenomenological study, based on Maurice MerleauPonty's theoretical-philosophical framework, which led us to recognize that "to look at an object is to inhabit it, and from this 
habitation to grasp all things, [...] it is completely displayed and its parts co-exist while our gaze runs from one to another, its present does not cancel its past, nor will its future cancel its present"(11).

Merleau-Pontyan phenomenology argues that the perception of the phenomenon always occurs in an ambiguous way, in a phenomenal field, where feeling and reflection are intertwined ${ }^{(11)}$. Such a perspective mobilizes us to understand the macro context in which the drug user and his family are involved; allows us to reflect on the correlations established by them in the world of life (feeling) and in the world of culture (reflecting), without defining cause and effect, with this, we can break the positivist logic and generate a reflexive counterargument on the subject ${ }^{(12)}$.

\section{Study setting}

The research field was the CAPS AD, located in a municipality in the south of Bahia, which was chosen as a space favorable to the expression of creativity, life building and bridges with society ${ }^{(13)}$. The choice also occurred from the need to develop studies that reveal new possibilities to look at the process of psychosocial rehabilitation proposed in this field, because the increase in the implantation of this type of service does not correspond to the number of publications, which, besides being insufficient, are concentrated in the postgraduate centers spread throughout the country ${ }^{(14)}$.

\section{Data source}

Eleven CAPS AD users participated in the study, being ten men and one woman; among men, eight declared themselves singles and two married; and the woman declared herself single. They began to use drugs between the ages of 10 and 20 years, and all were followed up at CAPS AD for over a year. In relation to the family bond, only one declared that they did not have a family, two lived with a family member, and the others maintained the bond through social networks, telephone calls, virtual and face-to-face meetings. As inclusion criteria, were adopted: to be a registered user and under treatment in CAPS AD for at least six months; attend the service at least three days/week; and be over 18 years of age. In order to preserve anonymity, gemstone codenames were assigned to the participants.

\section{Collection and data organization}

The production of experiential descriptions occurred in August 2015, through two meetings of the Focal Group (FG), lasting approximately one and a half hours, held in the CAPS AD living room under the facilitation of a mediator (research coordinator) and an observer. The observer recorded the discussion of the meeting without making inferences, and the mediator encouraged participants to speak freely; encouraging them to express feelings, opinions and opinions about their family perceptions; and in addition to keeping the discussion focused, he summarized and resumed the subject when someone got away from it ${ }^{(15)}$.

The open-ended question "comment on what family means to you" section, related to the study topic, triggered the dialogue and guided the meeting's discussions. Based on Merleau-Ponty's framework, we sought to dialogue with participants to get closer to the things themselves, to opportunize the unveiling of the context and to ensure that the phenomenon was perceived in itself so that we could know the experience lived ${ }^{(11)}$. The speeches of FG were recorded on digital equipment, as agreed by participants.

\section{Data analysis}

The descriptions experienced were submitted to the Analytical Technique of Ambiguity, which consisted in the operationalization of the following steps: construction of the text from the transcription of the recordings in full; thorough readings of the text in order to recognize the phenomena in themselves, from themselves, through the figure-background gaze established by the perceptive exercise; defining the thematic axes that were expressed as ambiguities, that is, they were unveiled according to the interweaving of human dimensions: sensitive (feeling) and reflexive (thought) ${ }^{(16)}$. With this, the FG result was not an exchange of information, but a way to construct other possibilities $^{(17)}$. The study unveiled the Nuances of being family: materialist and existential view, which was discussed in the results.

\section{RESULTS}

According to the Merleau-Pontyan philosophy, things must be perceived from their intersubjective existence. Therefore, the research was developed from this perspective, not as an attempt to formulate explanations for phenomena revealed to perception, since we would risk losing the ability to recognize what exists beyond the objective plane. For that, we had to abandon the empiricist postulate of the priority of contents and be free to recognize the singular mode of existence that occurs to us through perception ${ }^{(11)}$.

This article, which aims to understand the perception of drug users about "being a family" in the context of their psychosocial rehabilitation, revealed that any attempt by participants to objectify what it is to be a family was insufficient to express the meaning of the experience. Thus, we recognize that the Nuances of being family: materialist and existential view, objectified as a result of the study, appeared as an ambiguity of the perceptive process, which "manifests now with a sensitive experience, sometimes as a reflective experience ${ }^{\prime \prime(17)}$.

Likewise, it was possible to understand the perception of drug users about "being a famil" according to two perspectives: the first, unveiled as materialist, linked to the very socioanthropological construction of users in this modern Western society whose characters we all inherit: principles, values moral and ethical, beliefs, customs, that reinforce more the having, instead of being, linking the relations to the utilitarian one; and another, more existentialist, oriented by instinctive feelings of belonging and affectivity.

In thethe materialist perspective, study participants revealed that "being a family" is meeting the needs of its members, regardless of differences. At the moment users most need, they rely on the family, who generally do not deny care, since they place great expectations on it, as we see in the descriptions below:

Family is someone we can count on. Even with some fights, disagreements between members, of course, at the moment that people most need them, they will be by our side. It's a true friendship, someone we can count on. (Pearl) 
Family are those true friendships that help you, even though they are not your relatives. (Topaz)

Still from this perspective, the family relationship seems to have been established by a utilitarian one. The family, besides being present in the diverse situations of the life, needed to offer help and support of all the forms, including financial, as it appeared in the following descriptions:

I was already arrested in a prison. For you to have an idea: I bought drugs and I didn't pay for them, but my family deposited the money, tried to help me anyway. (Topaz)

At no point in my life did my family leave me without support. My family supports me. They pay my rent, on the right day, they send me food so I can cook it. (Emerald)

I am the brother my sisters like the most. It's me they seek. I can help, I help; Also, when I need them, they help me back. (Tourmaline)

The family is the formation of a genetic group that, within the society, helps one another. (Diamond)

I call my mother and she asks "My son, what do you need?" I call my sister, she says the same thing; I call my brother, he says the same thing.. (Emerald)

Regarding the existentialist perspective, the statements showed that "being a family" is to have an affective bond, in such a way that the person is able to recognize affection, companionship, friendship, loyalty and union as necessary feelings in the constitution of "being a family". Intersubjectivity showed that the family relationship should guarantee its members support, guidance, tolerance, donation, indissolubility, affection, commitment, respect and understanding, as the statements:

Family is affection, caress, companionship, true friendship. (Pearl)

Family for me is a good person. (Tourmaline)

Family is complicity, loyalty, legion of goodwill. (Amethyst)

I have family, now, family for me, there must have union, when we there isn't union with the family, nothing goes right. (Tourmaline)

Family is the one that supports and listens, so I can talk about my life, and they help me to find a solution for the problem. (Ruby)

No one would bear our temper, the way they do. This is very important, I'm happy because of that, right? I'm happy because someone cares for us. (Pearl)

My father and mother never left me. (Jade)

The affective bond sent the participants of the study to the idea of coexistence in the world, and with this, it occurred to them that they were not alone, a sense of belonging, origin, connection to others, even to God, as the descriptions follow:
I could never say that I was generated by a stranger, I was raised by my mother and mother is family, brother is family. (Topaz)

My father cares for me a lot, I thank him for everything, for this great family, he does almost the impossible to make me feel well. (Jade)

The family is the one that cares for the children, cares for the woman and gives moral lesson for us to learn. (Agate)

Family is God. We are fruit from God. God is family, He never left me. God is so faithful that He never abandoned me. (Jade)

The study showed the permanence of the nuclear family model in the participants' reflection. Even in a modern society surrounded by new family arrangements, in this study, the family is perceived at the nuclear level as that composed by father, mother, grandparents, as we observe below:

Family for me means a good tree. And today I thank God for this family, which is unique: my father and my mother. (Jade)

It is important to have a father, a mother, who is near you. (Agate)

In this context, the mother's figure was unveiled and correlated to the manifestations of affection. The mother was perceived as the one who welcomes, cares and caresses; always willing to help, to support. And at the moment when the child is marginalized, without the comfort of home, due to the habitual condition of alcohol and/or other drugs abuse, the mother was the figure who sought to welcome the child and reintegrate him/ her into the family, as revealed the descriptions:

Of the whole family, she [the Mother] is the main one, she is the base. I slept in the street, who opened the door for me to sleep in the house was this old lady, my mother. [...] I have a father that is not a father, he is a mother. He is more than a father, do you understand? (Jade)

In relation to my family, my mother is the best. (Emerald)

We have privilege because we have a mother at home and another one here at CAPS AD. (Pearl)

The participants recognized that the family is the foundation of their lives, perceived it as their point of support and endorsement, as "the basis of everything". It was through the family that they began to enter into life, as the speeches revealed:

My family is the foundation, it is my structure, without my family I was in the cemetery. (Emerald)

In my conception, family is the basis of everything, we can cite here " $N$ " words in relation to the family, only that all will be summed up in life. (Axinite)

The participants also reported that in order to be a family, one does not necessarily have to have consanguinity, but rather a relationship capable of producing affection, which motivates the human being to recognize solidarity, complicity, generosity, benevolence, goodness, 
love and faithfulness. In fact, that participant who claimed to have no family pointed out the relationship with God as something capable of providing this bond, so that God also appeared as a member of the family, as we see in the following statements:

So for me, family are those true friendships that help you, even though they are not your relativs. For me, this is the family. (Topaz).

Today I have this family, who is my mother-in-law and my father-in-law, they give me several opportunities. My wife suffers for me, but with faith in God I'm turning this around and going back to my family. (Amethyst)

\section{I found here in CAPS AD a second family. (Ruby)}

My family is the people of CAPS AD because I don't have a father, I don't have a mother, I don't have a grandmother, my family is these people. I live in the Recovery Center and I treat them like my family. (Agate)

I have no relative and I live with God. I have nothing in my life, only God and these people who welcome me from the heart. (Agate)

\section{DISCUSSION}

In unveiling the perception of "being a family", the study participants did so through two ambiguous aspects: now existential, now material; so that both were revealed as profiles of the same coin, full of our existence and indissoluble in our understanding of what it is to be a family in the $21^{\text {st }}$ century.

Thus, we consider that the results of the study regarding the meaning of "being a family", according to the perception of CAPS $A D$ users, are seen from two perspectives. The first of them seems to converge to a more materialistic sense, revealing, to a certain extent, a utilitarian view, that is, "being a family" means being useful, meeting the needs and expectations of their consanguineals, be they material, affective or relational. It is, therefore, a perspective that understands interpersonal relations as tending to be remodeled "in the likeness of the means and objects of consumption and along the lines suggested by the consumerist syndrome"(18).

To be sure, we live in the context of contemporary discussions about a discard society. He who is not always willing to serve us in our needs is subject to discard. This is also the case in the family context ${ }^{(18)}$. In Western societies, like our own, the power of the dominant culture comes to intertwine in certain behaviors and attitudes, or to participate in certain practices which, on the moralistic and reflective level, perhaps we would never approve of and would be horrified with.

We have learned in our culture that the family should always be willing to support its members, regardless of what happens to them ${ }^{(4)}$. It is not uncommon to hear of families who, if one of the members is arrested for drug trafficking or theft, pay bail to free him from prison. For some consumers of alcohol and other drugs, if the family does not indulge in this and other "generosity" practices, it can not be considered as a family.

In Merleau-Ponty's writings, we find that he is bent on arguing against the objectivist view, that which regards the world as a set of things in themselves, which are separate from us ${ }^{(10)}$. For the philosopher, between man and all other created things there is a universality, an interweaving, which makes them one and binds them. Therefore, there is no dichotomy between man and nature, soul and body, consciousness and world, subject and object ${ }^{(11,19)}$.

This author's thinking fits with the participants' perception that universality and intertwining occurring in the family context should mobilize family members to do something to help them, even when engaging in illicit acts. However, the descriptions show that the "something" that the study participants expect from the family has to do with meeting material, affective and relational needs, so that it reveals an objectivist view, in considering the possibility of a dichotomy between them and family, in case this does not do what they expect.

On the other hand, the "being family" can flow into a more existentialist sense, showing, in a certain way, a perception of affectivity and belonging, corresponding to a bond that one has, to a feeling that the person did not arise chaotically, was born of someone ${ }^{(20)}$. And this perspective reminds us of Merleau-Ponty's thought that we are not separate from the world, things, and the other, but intertwined with them ${ }^{(11)}$.

The retaking of the primordial question of Merleau-Ponty, of which we are an incarnate consciousness, reveals the main thesis on which the philosopher resolutely rejects - the dichotomy of soul and body, consciousness and world, man and nature - and which is strengthened by the utilitarian perspective. In this perspective, the dichotomous understanding of the family-participant or the subject-world relationship strongly influences the effectiveness of the proposal for psychosocial rehabilitation, especially regarding the context of family participation in the process.

All these reflections make us understand that the social transformations that occurred in the twentieth century caused the family to cease to be seen only as a procreation unit to be seen as generating new forms of coexistence, with mutual commitment and responsibility among its members ${ }^{(21)}$. For this, the family must offer love, affection, caress, solidarity, education and reciprocal respect; extrapolate inbreeding; besides giving material comfort to its members. In this sense, the successful family must be able to build new links with significant people at the level of their geographic and existential territories ${ }^{(5)}$.

Thus, the study reveals both the perception of family in the materialist context, and in the existential context. It was pointed out as "the basis of everything" and also, as a social support of the human being ${ }^{(22)}$, perceptions such as portray the conventional view that the family is undoubtedly the first social cell(23), a place of coexistence and learning, considered as the primary social care unit ${ }^{(3)}$. The Constitution of the Federative Republic of Brazil of 1988, in its article 226, presents the family as the base of the society and that, therefore, it must have special protection of the State ${ }^{(24)}$.

Thus, the participants correlated the "being a family" with the affective bond and made us reflect that, at the level of coexistence, we are born of someone, we originate from another, we are not isolated, that is, we are not punctual, which reveals a feeling underlying a human being of being connected to someone and echoing the Merleau-Pontyan thought that the world did not arise chaotically, and things are linked to one another. 
Therefore, the affective bond between the person and his/ her family was revealed as existential, an idea that offered support to the participants' speeches about which family is the one that "provides support", "affection", "attention", among other characteristics of affectionate relations, immanent to the human being, that emerge from the feeling of belonging and attachment to others, to things and to the world ${ }^{(11)}$.

The study revealed that actions of psychosocial rehabilitation in the context of drug use can be strengthened by affective and intertwined relationships in which users of mental health services and their families organize, support and solidify care. The family appeared as one of the devices of the network of attention in mental health essential to the process of psychosocial rehabilitation, although its own conception underwent several transformations and important social impacts, that implied in significant alterations in the contemporary context.

\section{Study limitations}

Because it is a study that aims to know the profiles that are revealed in human perception, we know that every time we read the speeches of the participants, we will have many other perceptions about the study, however, makes it possible for us to write only about some profiles, which agrees with MerleauPonty's thinking that knowledge is unfinished and that it is always necessary to carry out new readings of experiential descriptions. The study highlights the need to conduct new research aimed at listening to family members of drug users about "being a family".

\section{Contributions to the health sector}

This article constitutes an important knowledge for the reflection of nurses, also of all the mental health team, as well as of the public health management, at the moment of the reformulation of policies and models of attention, since, in the scope of the care, it has already been agreed that the family corresponds to a primary care device in the composition of the network.

In the midst of a series of conceptual changes, the family is called to play an effective role in the consolidation of the psychosocial model in mental health. To do this, they must be given an active voice, as well as the users of the services who wish to be heard as to what they feel and think. The initial intention of the present study was not exactly to know the meaning of "being a family", but at the same time that the users of CAPS AD revealed the need for the family to be inserted in their psychosocial rehabilitation, they made the sense of "being a family" for them and their descriptions led us to the construction of this article.

\section{FINAL CONSIDERATIONS}

The article presented results referring to the excellent listening of CAPS AD users about the meaning of "being a family" in the context of their psychosocial rehabilitation and made us reflect on the need for the interdisciplinary team of this device to contribute to the reconstruction of the user-family bond, which may awaken in the family the desire to become involved both in the therapeutic process of the user and in the network of mental health care, as proposed by the Ministry of Health (MS-Ministério da Súde).

Merleau-Ponty's philosophical framework allowed for the attentive look at the experiential descriptions produced with the study participants, through the figure-background reading, an artistic way of doing research that rescues Nursing ways of being, as a science and as art. From this reading, it was possible to understand two meanings in relation to "being a family", according to the perspective of drug users, which we configured as: a more materialistic and utilitarian view, and another more existential.

The first perspective is based on Merleau-Pontyan thought in relation to sociocultural influence in men's ways of being and doing, a thought that resonates with the notion of a liquid society whose main characteristic is consumerism and utilitarianism, even in the context of interpersonal relationships, in the family and in the social environment. The second perspective is also based on Merleau-Ponty, when it comes to the sensitive experience or world of feelings, which includes the sense of belonging and coexistence present in the descriptions of users of CAPS AD in relation to their families.

Through the above, we believe that the existentialist view presented by the users is useful to our reflection on humanity and that we need to keep alive the social relations capable of producing solidarity, kindness, affectivity, generosity, among others. With this, consumer care practices of alcohol and other drugs that recognize and dignify the human being, that respect their choices and offer diverse possibilities to become another "myself".

The relations established with the world, with man and with things reflect this link of the consumer of alcohol and other drugs with the human essence, so that the development of practices that favor the transcendence of the sentient being, based on a listening capable of promote this connection, should include the involvement of managers, health professionals, family and community in care actions, which suggest the insertion of all significant people for him, regardless of whether or not they have blood ties.

\section{REFERENCES}

1. Mangueira SO, Lopes MVO. Dysfunctional family in the context of alcoholism: concept analysis. Rev Bras Enferm[Internet]. 2014[cited 2015 Feb 10];67(1):149-54. Available from: http://www.scielo.br/pdf/reben/v67n1/0034-7167-reben-67-01-0149.pdf

2. Nunes ECDA, Silva LWS. Nurse subjectivity expressing the significance of family care through art. Texto Contexto Enferm[Internet]. 2011[cited 2015 Feb 10];20(3):453-60. Available from: http://www.scielo.br/pdf/tce/v20n3/05.pdf

3. Soccol KLS, Terra MG, Girardon-Perline NMO, Ribeiro DB, Silva CT, Camillo LA. Family care to individuals dependent on alcohol and other drugs. Rev Rene[Internet]. 2013[cited 2015 Feb 10];14(3):549-57. Available from: http://www.revistarene.ufc.br/revista/ index.php/revista/article/view/1104 
4. Souza ABL, Beleza MCM, Andrade RFC. New family arrangements and challenges to family law: a reading from the court of Amazon. PRACS[Internet]. 2012[cited 2015 Mar 15];5:105-19. Available from: http://periodicos.unifap.br/index.php/pracs/article/ viewArticle/577

5. Figueiredo MHJS, Martins MMFPS. From practice contexts towards (co)construction of family nursing care models. Rev Esc Enferm USP[Internet]. 2009[cited 2015 Mar 15];43(3):615-21. Available from: http://www.scielo.br/pdf/reeusp/v43n3/a17v43n3.pdf

6. Silva BLC, Araújo AP, Carvalho RN, Azevedo EB, Moraes MN, Queiroz D. Participation of family members in the treatment of alcohol and drug users from the psychosocial care center. Rev Bras Pesq Saúde[Internet]. 2012[cited 2015 Mar 25];14(4):61-6. Available from: http: www.periodicos.ufes.br/RBPS/article/download/5120/3846

7. Brasil. Ministério da Saúde. Secretaria de Atenção à Saúde. DAPE. Coordenação Geral de Saúde Mental. Reforma psiquiátrica e política de saúde mental no Brasil. Documento apresentado à Conferência Regional de Reforma dos Serviços de Saúde Mental: 15 anos depois de Caracas. Brasília: OPAS; 2005[cited 2015 Mar 25]. Available from: http://bvsms.saude.gov.br/bvs/publicacoes/ Relatorio15_anos_Caracas.pdf

8. Alvarez SQ, Gomes GC, Oliveira AMN, Xavier DM. Support group as a strategy of care: the importance for relatives of drug users. Rev Gaúcha Enferm[Internet]. 2012[cited 2015 Mar 25];33(2):102-8. Available from: http://www.scielo.br/pdf/rgenf/v33n2/15

9. Sena ELS, Boery RNSO, Carvalho PAL, Reis HFT, Marques AMN. Alcoholism in family context: a phenomenological approach. Texto Contexto Enferm[Internet]. 2011[cited 2015 Apr 11];20(2):310-18. Available from: http://www.scielo.br/pdf/tce/v20n2/a13v20n2.pdf

10. Brasil. Ministério da Saúde. Conselho Nacional de Saúde-CNS. Resolução No 466 de 12 de dezembro de 2012. Dispõe sobre Diretrizes e Normas Regulamentadoras de Pesquisa envolvendo seres humanos. Brasília: MS; 2012[cited 2015 Feb 25]. Available from: http://bvsms.saude.gov.br/bvs/saudelegis/cns/2013/res0466_12_12_2012.html

11. Merleau-Ponty M. A fenomenologia da percepção. 4 ed. São Paulo: Martins Fontes; 2011.

12. Reis HFT, Moreira TO. Crack in the family's context: a phenomenological approach. Texto Contexto Enferm[Internet]. 2013[cited 2015 Aug 18];22(4):1115-23. Available from: http://www.scielo.br/pdf/tce/v22n4/30.pdf

13. Azevedo DM, Miranda FAN. Professional practice and treatment offered in CAPS ad in the city of Natal-RN: with the word, the family. Esc Anna Nery Rev Enferm[Internet]. 2010[cited 2015 Aug 10];14(1):56-63. Available from: http://www.scielo.br/pdf/ean/ v14n1/v14n1a09.pdf

14. Zanatta AB, Garghetti FC, Lucca SR. Psychosocial attention center for alcohol and other drugs in the perception of user. Rev Baiana Saúde Pública[Internet]. 2012[cited 2015 Aug 10];36(1):225-37. Available from: http://files.bvs.br/upload/S/0100-0233/2012/ v36n1/a3011.pdf

15. Trad LAB. Focal groups: concepts, procedures and reflections based on practical experiences of research works in the health area. Physis[Internet]. 2009[cited 2015 Feb 10];19(3):777-96. Available from: http://www.scielo.br/pdf/physis/v19n3/a13v19n3.pdf

16. Sena ELS, Gonçalves LHT, Müller Granzotto MJ, Carvalho PAL, Reis HFT. Analytics of ambiguity: methodological strategy to the phenomenological research in health. Rev Gaúcha Enferm[Internet]. 2010[cited 2015 Feb 15];31(4):769-75. Available from: http:// www.scielo.br/pdf/rgenf/v31n4/a22v31n4.pdf

17. Sena ELS, Carvalho PAL, Reis HFT, Souza VS. The care intersubjectivity and the knowledge in the phenomenological perspective. Rev Rene[Internet]. 2011 [cited 2015 Feb 15];12(1):181-8. Available from: http://www.revistarene.ufc.br/vol12n1_pdf/a24v12n1.pdf

18. Bauman Z. Vida Liquida. $2^{\text {a }}$ ed. Rio de Janeiro: Zahar; 2009.

19. Merleau-Ponty M. A prosa do mundo. São Paulo: Cosac \& Naify; 2002.

20. Silva VA, Marcon SS, Sales CA. Perceptions of family members of patients with cancer on musical encounters during the antineoplastic treatment. Rev Bras Enferm[Internet]. 2014[cited 2015 Sep 25];67(3):408-14. Available from: http://www.scielo.br/pdf/reben/ v67n3/0034-7167-reben-67-03-0408.pdf

21. Vianna RC. O instituto da família e a valorização do afeto como princípio norteador das novas espécies da instituição no ordenamento jurídico brasileiro. Rev Esmesc[Internet]. 2011[cited 2015 Sep 25];18 (24):511-36. Available from: http://www.revista.esmesc.org. br/re/article/view/41/45

22. Gabardo RM, Junges JR, Selli L. Arreglos familiares e implicaciones a la salud en la visión de los profesionales del Programa Salud da la Familia. Rev Saúde Pública[Internet]. 2009[cited 2015 May 25];43(1):91-7. Available from: http://www.scielo.br/pdf/rsp/ v43n1/6943.pdf

23. Teixeira LC, Parente FS, Boris GDB. New family settings and their subjective implications: assisted reproduction and female monoparental family. Psico[Internet]. 2009[cited 2015 Mar 25];40(1):24-31. Available from: http://revistaseletronicas.pucrs.br/ojs/ index.php/revistapsico/article/view/2848/4138

24. Brasil. Constituição da República Federativa do Brasil[Internet]. 1988[cited 2015 Mar 25]. Available from: http://www.planalto. gov.br/ccivil_03/constituicao/constituicao.htm 